\title{
Antibacterial potentiality of Argemone mexicana solvent extracts against some pathogenic bacteria
}

\author{
Indranil Bhattacharjee, Soroj Kumar Chatterjee, Soumendranath Chatterjee, \\ Goutam Chandra ${ }^{+}$
}

\begin{abstract}
Microbiology Research Unit, Parasitology Research Laboratory, Department of Zoology, The University of Burdwan, Burdwan-713104, West Bengal, India
\end{abstract}

The sensitivity of two Gram positive (Staphylococcus aureus and Bacillus subtilis) and two Gram negative (Escherichia coli and Pseudomonas aeruginosa) pathogenic multi-drug resistant bacteria was tested against the crude extracts (cold aqueous, hot aqueous, and methanol extracts) of leaves and seeds of Argemone mexicana $L$. (Papaveraceae) by agar well diffusion method. Though all the extracts were found effective, yet the methanol extract showed maximum inhibition against the test microorganisms followed by hot aqueous extract and cold aqueous extract.

Key words: Argemone mexicana - medicinal plant - antibacterial activity

Medicinal plants being the effective source of both traditional and modern medicines, are genuinely useful for primary health care. Over the years, World Health Organization (WHO) advocated traditional medicines as safe remedies for ailments of both microbial and non-microbial origins (WHO 1978).

Some antibiotics have become almost obsolete because of drug resistance (Ekpendu et al. 1994) and consequently new drugs must be sought for. Herbal treatment is one possible way to treat diseases caused by multidrug resistant bacteria (Olukoya et al.1993).

Though pharmacological industries have produced a number of new antibiotics in the last three decades, yet resistance to these drugs by microorganisms has developed. In general, bacteria have the genetic ability to transmit and acquire resistance to drugs, which in turn may be utilized as therapeutic agents (Cohen 1992).

The use of plant extracts and phytochemicals, with known antibacterial properties, may be of immense importance in therapeutic treatments. In the past few years, a number of studies have been conducted in different countries to prove such efficiency (Ikram \& Inamul 1984, Almagboul et al. 1985, Sousa et al. 1991, Kubo et al. 1993, Shapoval et al. 1994, Artizzu et al. 1995, Izzo et al. 1995). According to the WHO (Santos et al.1995), medicinal plants would be the best source for obtaining a variety of drugs. About $80 \%$ population of the developed countries use traditional medicines, derived from medicinal plants. Therefore, such plants should be investigated thoroughly to determine their structural and functional properties, as well as the efficiency of various parts (Ellof 1998).

Argemone mexicana L. (Papaveraceae), commonly known as prickly poppy, is used as a medicinal plant in

${ }^{+}$Corresponding author: goutamchandra63@yahoo.co.in Received 10 March 2006

Accepted 19 July 2006 several countries. In Mexico, the seeds are considered as an antidote to snake venom. In India, the smokes of the seeds are used to relieve toothache. The fresh yellow, milky seed extract contains protein-dissolving substances, effective in the treatment of warts, cold sores, cutaneous infections, skin diseases, itches, and also dropsy and jaundice (Chopra et al. 1986).

The present study has been designed to determine the role of seeds and leaf extracts (cold aqueous, hot aqueous, and methanol extracts) of A. mexicana for potential antibacterial activity, if any, against two Gram positive bacteria (Staphylococcus aureus MTCC 2940 and Bacillus subtilis MTCC 441) and two Gram negative bacteria (Escherichia coli MTCC 739 and Pseudomonas aeruginosa MTCC 2453).

\section{MATERIALS AND METHODS}

The plant material used in this study consisted of leaves and seeds of $A$. mexicana, collected from a village named Lakudi of Burdwan district ( $\left.23^{\circ} 16^{\prime} \mathrm{N}, 87^{\circ} 54^{\prime} \mathrm{E}\right)$, WB, India, during spring (mid-March to mid-April 2004). The leaves and seeds were initially rinsed with distilled water and dried on paper towel in laboratory at $(37 \pm 1)^{\circ} \mathrm{C}$ for $24 \mathrm{~h}$.

Preparation and preservation of plant extract

Cold aqueous extract - $50 \mathrm{~g}$, each of the two samples, A. mexicana leaves and seeds, were weighed out and soaked separately into $200 \mathrm{ml}$ cold water in a conical flask stoppered with rubber corks and left undisturbed for $24 \mathrm{~h}$, then filtered off using sterile filter paper (Whattman no. 1) into a clean conical flask and subjected to water bath evaporation, where the aqueous solvent was evaporated at its boiling temperature of $100^{\circ} \mathrm{C}$. The standard extracts obtained were then stored in a refrigerator at $4{ }^{\circ} \mathrm{C}$ for further use (Akueshi et al. 2002).

Hot aqueous extract - $50 \mathrm{~g}$, each of the two samples, A. mexicana leaves and seeds, were weighed out and soaked separately into $200 \mathrm{ml}$ hot water which was then boiled for $30 \mathrm{~min}$ (Akueshi et al. 2002) and kept in a coni- 
cal flask for $24 \mathrm{~h}$ undisturbed. The other steps were the same as followed in case of cold aqueous extract.

Methanol extract - After drying, the plant materials were ground in a grinding machine (MX-110PN, Japan) in the laboratory. Exposure to sunlight was avoided to prevent the loss of active components; $200 \mathrm{ml}$ of a methanol extraction fluid was mixed with $50 \mathrm{~g}$, each of the powdered plant material. The mixtures were kept for $24 \mathrm{~h}$ in tightly sealed vessels at room temperature, protected from sunlight and mixed several times with a sterile glass rod. This mixture was filtered through Whattman no. 1 filter paper and the residue, adjusted to the required concentration $(50 \mathrm{ml}$ of methanol for the residue of $50 \mathrm{~g}$ of powdered plant material) with the extraction fluid for further extraction and it was repeated thrice and a clear colorless supernatant extraction liquid was finally obtained. The extracted liquid was subjected to rotary evaporation in order to remove the methanol. The semisolid extract produced was kept in a freezer at $-80^{\circ} \mathrm{C}$ (REVCO model no. ULT 790-3V32) overnight and then subjected to freeze drying for 24 $\mathrm{h}$ at $-60^{\circ} \mathrm{C}$ in $200 \mathrm{ml}$ vacuum. Then the extract was stored in an airtight container at $4^{\circ} \mathrm{C}$ in refrigerator for further use.

All the dried extracts were exposed to UV rays (200$400 \mathrm{~nm}$ ) for $24 \mathrm{~h}$ and checked frequently for sterility by streaking on nutrient agar plates (Chessbrough 2000).

Antibacterial assay

Disc diffusion method - Antibiogram was done by disc diffusion method (Bauer et al. 1966, NCCLS 1993) using commonly used antibiotics. The surfaces of the media were inoculated with bacteria from a broth culture. High potency bio-discs (Himedia) were placed on the agar. After $18 \mathrm{~h}$ of incubation at a specific temperature $\left[(30 \pm 1)^{\circ} \mathrm{C}\right.$ for $B$. subtilis and $37^{\circ} \mathrm{C}$ for $S$. aureus, E. coli and $P$. aeruginosa], the plates were examined and the diameters of the inhibition zones were measured to the nearest millimeter.

Agar-well diffusion method - The assay was conducted by agar well diffusion method (Perez et al. 1990). The bacterial strains grown on nutrient agar at $37^{\circ} \mathrm{C}$ for 18 $\mathrm{h}$ were suspended in a saline solution $(0.85 \% \mathrm{NaCl})$ and adjusted to a turbidity of 0.5 Mac Farland standards $\left(10^{8}\right.$ $\mathrm{CFU} / \mathrm{ml}$ ). The suspension was used to inoculate $90 \mathrm{~mm}$ diameter petri. Wells ( $6 \mathrm{~mm}$ diameter) were punched in the agar and filled with $50 \mu \mathrm{l}$ of $2000 \mu \mathrm{g} / \mathrm{ml}$ extracts. The dissolution of the organic extracts (Methanol) was aided by $1 \%(\mathrm{v} / \mathrm{v})$ DMSO and that of the aqueous extracts with water, which did not effect the growth of microorganisms, in accordance with our control experiments. Plates were incubated in air at $37^{\circ} \mathrm{C}$ for $24 \mathrm{~h}$. Antibacterial activities were evaluated by measuring inhibition zone diameters. The experiments were conducted thrice. DMSO was taken as control for the methanol extracts. Sterile distilled water was taken as control for aqueous extracts, both hot and cold.

Test microorganism - Four bacterial strains were used during the study. Gram positive bacteria include $S$. aureus MTCC 2940 and B. subtilis MTCC 441 and Gram negative bacteria include E. coli MTCC 739 and P. aeruginosa MTCC 2453. All the tested strains are reference strains and were obtained from The Microbiology Laboratory of Burdwan Medical College and Hospital. The bacteria were grown in nutrient broth (Himedia, M002) at $37^{\circ} \mathrm{C}$ and maintained on nutrient agar slants at $4^{\circ} \mathrm{C}$.

\section{RESULTS}

Antibiogram of some common antibiotics against test microorganism - Antibiogram of the Gram positive and Gram negative bacteria revealed that all the bacterial strains were resistant to some widely used broad-spectrum antibiotics. However, all the bacteria were sensitive to the new generation antibiotics except $B$. subtilis because due to complex growth requirements, definitive NCCLS cut off values for antibiotics sucesptibility and resistance have not been established (Table I). All the values given are the mean of the three sets of observations and for the sake of convenience it has been rounded off. E. coli strain was resistant to and P. aeruginosa was sensitive to several antibiotics. Gatifloxacin was the most effective antibiotic against all the reference bacteria.

Antimicrobial sensitivity assay of different extract The antimicrobial screening of the plant extracts of the leaves and seeds of $A$. mexicana on P. aeruginosa, $S$. aureus, E. coli, and B. subtilis revealed that the seed extracts were more effective than those of the leaf extracts. The antibacterial activity of methanol extracts of $A$. mexicana (leaves and seeds) showed considerably more efficacy than the hot aqueous and cold aqueous extracts against all the reference bacterial strains.

The methanol extracts of $A$. mexicana (leaves and seeds) showed maximum antibacterial activity against $P$. aeruginosa, followed by E. coli, B. sublitis, and S. aureus. On the contrary, aqueous extracts (cold and hot) of $A$. mexicana seeds showed maximum activity against $B$. subtilis, followed by P. aeruginosa, E. coli, and S. aureus. Again, cold aqueous extract of $A$. mexicana leaves showed highest efficacy against $P$. aeruginosa followed by $B$. subtilis, E. coli, and $S$. aureus where as in case of hot aqueous extract of $A$. mexicana leaves, maximum sensitivity was shown against $E$. coli, followed by B. subtilis, $P$. aeruginosa, and $S$. aureus (Table II). All the values given, are the mean of three sets of data and for the sake of convenience, it has been rounded off.

\section{DISCUSSION}

The methanol extracts of the leaves and seeds of the A. mexicana showed greater antibacterial activity than the corresponding water extracts. This finding is interesting, because in the traditional method of treating a bacterial infection, decoction of the plant parts or boiling the plant in water is employed. Whereas, according to present study, preparing an extract with an organic solvent was shown to provide a better antibacterial activity, in accordance with the results obtained by Nair et al. (2005).

These observations may be attributed to two reasons: firstly, the nature of biological active components whose activity can be enhanced in the presence of methanol; 
TABLE I

Susceptibility of four reference bacterial strains to some antibiotics in nutrient agar

\begin{tabular}{|c|c|c|c|c|}
\hline \multirow[b]{2}{*}{ Antibiotics $(\mu \mathrm{g} / \mathrm{ml})$} & \multicolumn{4}{|c|}{ Diameter of the inhibitory zones (mm) } \\
\hline & Pseudomonas aeruginosa & Staphylococcus aureus & Escherichia coli & Bacillus subtilis \\
\hline Amoxycillin (30) & 14 & 0 & 7 & 0 \\
\hline Ampicillin (10) & 0 & 0 & 0 & 0 \\
\hline $\operatorname{Amikacin}(30)$ & 28 & 28 & 0 & 29 \\
\hline Cotrimoxazole (25) & 38 & 21 & 0 & 14 \\
\hline Ciprofloxacin (5) & 32 & 25 & 27 & 31 \\
\hline Chloramphenicol (30) & 30 & 25 & 0 & 22 \\
\hline Cloxacillin (1) & 0 & 0 & 0 & 0 \\
\hline Cefadroxil (30) & 28 & 0 & 0 & 0 \\
\hline Cefuroxime $(30)$ & 0 & 0 & 0 & 0 \\
\hline Doxycycline (30) & 28 & 8 & 20 & 30 \\
\hline Erythromycin (15) & 25 & 12 & 0 & 22 \\
\hline Gentamycin $(10)$ & 21 & 23 & 22 & 19 \\
\hline Gatifloxacin (10) & 39 & 29 & 37 & 37 \\
\hline Kanamycin (30) & 33 & 11 & 10 & 26 \\
\hline Lomefloxacin (10) & 29 & 22 & 25 & 34 \\
\hline Levofloxacin (5) & 32 & 26 & 23 & 30 \\
\hline Nalidixic acid (30) & 0 & 0 & 11 & 20 \\
\hline Norfloxacin (10) & 25 & 17 & 24 & 0 \\
\hline Ofloxacin (5) & 27 & 18 & 20 & 20 \\
\hline Penicillin-G(10) & 0 & 0 & 0 & 0 \\
\hline Sparfloxacin (10) & 34 & 26 & 30 & 36 \\
\hline Tobramycin (10) & 22 & 16 & 0 & 17 \\
\hline Tetracyclin (30) & 0 & 0 & 12 & 25 \\
\hline
\end{tabular}

TABLE II

Antimicrobial sensitivity assay of aqueous and methanol extracts of leaves and seeds of Argemone mexicana

\begin{tabular}{lcccc}
\hline Different extracts of & & \multicolumn{2}{c}{ Diameter of the inhibitory zones (mm) } \\
\cline { 2 - 5 } A. mexicana leaf and seed & 14 & Pstaphylococcus aureus & Escherichia coli & Bacillus subtilis \\
\hline Cold aqueous extract of leaf & 13 & 8 & 10 & 12 \\
Cold aqueous extract of seed & 15 & 10 & 17 & 13 \\
Hot aqueous extract of leaf & 17 & 12 & 16 & 16 \\
Hot aqueous extract of seed & 19 & 14 & 19 & 18 \\
Methanol extract of leaf & 22 & 15 & 21 & 18 \\
Methanol extract of seed & 0 & 0 & 0 & 0 \\
Sterile distilled water & 0 & 0 & 0 & 0 \\
Dimethylsulphoxide & 0 & 0 & 0 \\
\hline
\end{tabular}

secondly, the stronger extraction capacity of methanol could have produced greater number of active constituents responsible for antibacterial activity.

The extracts of $A$. mexicana seeds under study showed greater antibacterial activity and the diameter of inhibition zone is higher than that of Ocimum gratissimum (Okigbo \& Omodamiro 2005), Syzyium aromaticum seed, Cinnamomum cassia bark, Salvia officinalis leaf, Thymus vulgaris leaf, Rosmarinus officinalis leaf (Shanab et al. 2004), Sapindus emarginatus, Hibiscus rosa sinensis, Mirabilis jalapa, Rheo discolor, Nyctanthes arbortristis, Colocasia esculenta, Gracilaria corticata, Dictyota spps., Pulicaria wightiana (Nair et al. 2005). So $A$. mexicana plant can be used to discover bioactive natural products that will lead to the development of new phar- maceuticals. Such screening of various natural organic compounds and identification of active agents must be considered as a fruitful approach in the search of new herbal drugs.

Moreover, seed extracts were more effective. But, in vivo study on this medicinal plant is necessary to determine toxicity of the active constituents, their side effects, serum-attainable levels, pharmacokinetic properties and diffusion in different body sites. The antimicrobial activities can be enhanced if the active components are purified and adequate dosage determined for proper administration.

This may go a long way in preventing the administration of inappropriate concentrations, a common practice among many traditional medical practitioners. 


\section{ACKNOWLEDGEMENTS}

To Department of Science and Technology, New Delhi, for providing instruments through FIST programme.

\section{REFERENCES}

Akueshi CO, Kadiri CO, Akueshi EU, Agina SE, Ngurukwem B 2002. Antimicrobial potentials of Hyptis sauvedens Poit (Lamiaccae), Nigeria. J Bot 15: 37-41.

Almagboul AZ, Bashir AK, Farouk A, Salih AKM 1985. Antimicrobial activity of certain Sudanese plants used in folkloric medicine. Screening for antibacterial activity. Fitoterapia 56: 331-337.

Artizzu N, Bonsignore L, Cottiglia F, Loy G 1995. Studies of the diuretic and antimicrobial activity of Cynodon dactylon essential oil. Fitoterapia 66: 174-175.

Bauer AW, Kirby WM, Sheris JC, Turck M 1966. Antibiotic susceptibility testing by a standardized single disc method. Am J Clin Pathol 45: 149-158.

Chessbrough M 2000. Medical Laboratory Manual for Tropical Countries, Linacre House, Jordan Hill, Oxford, 260 pp.

Chopra RN, Nayar SL, Chopra 1986. I. C. Glossary of Indian Medicinal Plants (Including the Supplement), Council of Scientific and Industrial Research, New Delhi.

Cohen ML 1992. Epidemiology of drug resistance: implications for a post-antimicrobial era. Science 257: 1050-1055.

Ekpendu TO, Akshomeju AA, Okogun JI 1994. Antinflamatory antimicrobial activity. Lett Appl Microbiol 30: 379-384.

Ellof JN 1998. Which extractant should be used for the screening and isolation of antimicrobial components from plants. $J$ Ethnopharmacol 60: 1-6.

Ikram M, Inamul H 1984. Screening of medicinal plants for antimicrobial activities. Fitoterapia 55: 62-64.

Izzo AA, Carlo Di, Biscardi G, Fusco D, Mascolo R, Borreli N, Capasso F, Fasulo F, Autore MP 1995. Biological screening of Italian medicinal plants for antibacterial activity. Phytother Res 9: 281-286.

Kubo L, Muroi H, Himejima M 1993. Structure-antibacterial activity relationships of anacardic acids. J Agri Food Chem 41: 1016-1019.

Nair R, Kalariya T, Sumitra C 2005. Antibacterial activity of some selected indian medicinal flora. Turk J Biol 29: 41-47.

NCCLS 1993. Performance standards for antimicrobial disc susceptibility tests. Approved standard NCCLS Publications M2-A5. Villanova, PA, US.

Okigbo RN, Omodamiro OD 2005. Antimicrobial effect of leaf extracts of pigeon pea (Cajanus cajan (L) Mill sp.) on some pathogens of man. J Herbs Spices Med Plants (in press).

Olukoya DK, Idika N, Odugbemi T 1993. Antibaterial activity of some medicinal plants from Nigeria. J Ethnopharmacol 39: 69-72.

Perez C, Pauli M, Bazerque P 1990. An antibiotic assay by the agar-well diffusion method. Acta Biol Med Exper 15: 113115 .

Santos PRV, Oliveira ACX, Tomassini TCB 1995. Controle microbiógico de produtos fitoterápicos. Rev Farm Bioquím 31: $35-38$

Shanab BA, Adwan G, Safiya AD, Jarrar N, Adwan K 2004. Antibacterial activities of some plant extracts utilized in popular medicine in Palaestine. Turk J Biol 28: 99-102.

Shapoval EES, Silveira SM, Miranda ML, Alice CB, Henriques AT 1994. Evaluation of some pharmacological activities of Eugenia uniflora. J Ethnopharmacol 44: 136-142.

Sousa M, Pinheiro C, Matos MEO, Matos FJ, Lacerda MI, Craveiro AA 1991. Constituintes Químicos de Plantas Medicinais Brasileiras, Universidade Federal do Ceará, Fortaleza, p. 385-388.

WHO 1978. The promotion and development of traditional medicine. Technical report series, $622 \mathrm{pp}$. 